\title{
Risky Business: Legal and Economic Perspectives on South Korea's Individual Debtor Rehabilitation Acts"
}

\author{
JASPER KIM**
}

Two years following the 1997-98 Korean financial crisis, the Korean government attempted to bolster consumer spending and re-invigorate the national economy by pursuing a series of policies that directly promoted the use of consumer credit cards. Subsequently, consumer credit card spiked upward, which led to a dramatic surge in individual debtor defaults. The government in response mode again thereafter initiated a three-pronged legislative effort to counter the post-1997 individual debtor polemic: (i) the Individual Debtor Rehabilitation Act ("IDRA" or the "Act"); (ii)) the Korea Asset Management Company's Bad Bank (KAMCO or "Bad Bank"); and (iii) the Credit Counseling and Recovery Service (CCRS) (collectively, the "Legal Acts"). This paper surveys and analyzes the Legal Acts approach to resolving South Korea's post-1997 consumer credit card spending polemic.

Keywords: South Korea, credit cards, moral hazard, default, delinquency, debt

\footnotetext{
The author would like to give a special acknowledgement to Min-Young Lee for her valuable research assistance relating to this paper.

**Associate Professor, Graduate School of International Studies; Ewha Womans University, 11-1 Daehyun-dong, Seodaemun-gu, Seoul, 120-750, South Korea; Tel: 82-2-3277-4077; E-mail: jaskim @ewha.ac.kr
} 


\section{INTRODUCTION}

S ince the 1997-98 Korean financial crisis ("1997-98 Crisis"), South Korea1 has increasingly become a nation of massive credit card defaulters. Most notably, in 2002, nearly ten percent of the entire Korean population, or nearly four million individuals, have defaulted ${ }^{2}$ on their personal credit card debts or loans, with little indication that conditions are about to improve. 3 Just prior to and following the 1997-98 Crisis, Korean households were predominantly debt free. 4 The conventional thought is that such crisis was a result of crony capitalism, as espoused by David Kang (2002). However, Chang et. al. (1998) argued that the crisis was caused by the dismantling of the "traditional regime" rather than a failure to incorporate a more Anglo-American financial infrastructure. Now, several years following the 1997-98 Crisis, Korean households hold an average household debt amount of approximately US\$27,000.5

The introduction of consumer credit cards by the Korean government following the 1997-98 Crisis was the first of two proposed solutions to boost domestic consumer spending. The first government initiative provided incentives for consumers to use credit cards, such as a $20 \%$ income tax deduction for those whose credit card expenditures totaled more than $10 \%$ of his or her annual income. ${ }^{6}$ The second government initiative provided deregulatory incentives to consumer credit card issuing institutions, including the lifting of long-held restrictions against cash advances. ${ }^{7}$

This paper will consist of three major components. First, an introduction will be provided relating to the circumstances surrounding the post-1997 South Korean credit card spending hangover. Second, a broad overview and discussion relating to the Legal Acts and its stated objectives will be given. Third, and finally, a policy analysis relating to the Legal Acts will be provided.

\section{SOUTH KOREAN CREDIT CARD SPENDING HANGOVER}

\section{Existing Literature}

Thus far, no literature currently exists that deals with individual credit defaulters from a legal and legislative purview within the South Korean context in the post-1997 period. Most existing research generally separates the two related issues of the credit defaulter problem and the credit card corporation delinquency problem, with most of the existing academic literature focusing on the latter issue of credit card corporation delinquency in relation to South Korean macro economic growth. Choi $(2004)^{8}$ discusses the credit defaulter issue generally and argues that the credit card companies' rampant issuance of credit cards did not constitute sound economic policy to stimulate macroeconomic growth. 
Although Choi does discuss several government countermeasure policies, the paper merely provides a general overview of each act, but does not focus on the legal issues within such acts. Similarly, the Korea Institute of Finance 9 also released a paper that analyzed Korean government policy relating to credit card defaulters, which argued for the greater use of revolving credit card lines (which is common in the U.S., but currently less widely adopted in South Korea) and other related structural reforms.

Other papers are dated, in that they are published in the pre-1997 period, such as in Dong-ki Kim's paper (1992) ${ }^{10}$ provided a broad and comprehensive non-legal overview of South Korean credit card policy (noting that almost no academic literature exists for the post-1997 period). Finally, Soo-Geun Oh (2004) ${ }^{11}$ discussed IDRA(the International Debtor Rehabilitation Act), but only in the context of a practical guide for interested credit defaulters who are seeking IDRA protection. For the following reasons, this paper attempts to fill such academic niche, which should be beneficial to both the academic community, as well as the financial community, who may be seeking greater clarity as to how such Legal Acts may impact the South Korean financial markets. ${ }^{12}$

\section{Post 1997-98: Legislation to Boost Consumer Confidence}

One notable problem following the 1997-98 Crises was the lack of consumer spending to revive the domestic economy. One piece of legislation to boost consumer spending from 1999 came in the form of a series of disparate government initiatives to promote the mass issuance of credit cards to individuals. ${ }^{13}$ The notable result however was that the solution of offering credit cards to boost consumer spending brought about another unforeseen problem in the form of a post credit card spending binge polemic. This occurred not because the government plan to promote credit card usage was not successful enough, but rather, because the credit card initiative was overly successful.

Evidence of the excessive credit card spending existed in various forms. For example, in late 2002, just a mere three years following the government's 1999 credit card initiative, Koreans quickly went from having very few or no credit cards to having an average of nearly four credit cards per person. ${ }^{14}$ Such added lines of credit quickly translated into increased consumer spending and increased gross domestic output. As evidence, in 1999, South Korean economic growth rate was an extremely robust $10.9 \%$, followed by an impressive $9.3 \%$ growth rate the following year in 2000.15

\section{Post-1997 Korea: The Over-consumption Polemic}

As overall economic conditions began to improve in South Korea, following the 1997-98 Crisis, domestic consumers began to spend beyond a rational level 
such that credit card usage went above and beyond repayment capacity. ${ }^{16}$ Crotty and Lee (2002) noted that such credit card binge spending was worrisome to the level that such behavior could trigger "an outbreak of distress on the household sector." By late 2002, South Korea's economy was weighed down with approximately US $\$ 100$ billion in credit card debt (not including personal loan debt obligations). ${ }^{17}$ This effectively amounted to debt levels that equaled nearly $75 \%$ of South Korea's 2003 annual economic output, totaling nearly US $\$ 365$ billion in household debt. 18

\section{Possible Legislative Assumptions}

Such a credit card polemic was in large part unforeseeable in a conservative nation that places a high priority on traditional Confucian ideals. Relating to this, Callahan (1999) argued that such Confucian interplay between China and South Korea would have a broader impact on South Koreans. In part due to such ideals, the government seemingly presumed that the potential of public dishonor of bankruptcy would mitigate both the likelihood of spending more than earnings and the potential of personal bankruptcies. ${ }^{19}$

The rapid availability for average nearly all Koreans, regardless of their ability to repay, to such credit lines - that could be spent at any time - proved overwhelming, especially given that most individual credit card debtors are on average under forty years of age. Additionally, because of the 1999 initiative, lack of detailed personal credit history information, and rigid privacy laws, credit cards could be obtained by many Koreans without proper credit checks. Table 1 below details the growing trend of credit card delinquencies in Korea from 1998 to 2003.

Table 1. Credit Card Delinquency Levels in South Korea (1998-2003)

\begin{tabular}{l|l|r|r|l|l|l}
\hline \multicolumn{1}{c|}{ YEAR } & 1998 & 1999 & 2000 & 2001 & 2002 & 2003 \\
\hline Credit Card Delinquents (million) & 193 & 199.6 & 208.4 & 245 & 263.6 & 372 \\
\hline Increase Amount & 50.1 & 6.6 & 8.8 & 36.6 & 18.6 & 108.4 \\
\hline
\end{tabular}

SOURCE: Ministry of Finance and Economy website (March 10, 2004)

\section{LEGISLATIVE OVERVIEW}

\section{Individual Debtor Rehabilitation Act (IDRA)}

Following the 1997-1998 Korean financial crisis, with national income and consumer confidence levels well below pre-1997 levels, in addition to a surge in unemployment, the Korean economy needed massive and drastic resuscitation. 
In response, the Korean government proposed two solutions to boost domestic consumer spending in 1999.20 First, the government provided a direct and aggressive incentive scheme for consumers using credit cards. ${ }^{21}$ Second, the government also provided deregulatory incentives to the financial institutions so that, even young consumers without sustainable income or a sound credit histories, could obtain consumer credit cards. Such drastic efforts were enacted with the objective of boosting domestic consumer consumption and confidence to boost the economy. 22

Specifically, three years after the government's remedy to boost consumer spending vis-à-vis legislation to boost the use of consumer credit cards, another economic crisis broke out in the form of high rates of credit card delinquency rates, which effectively added deadweight on an economy that was on the verge of recovery. On the consumer side, Korean consumers who, before such deregulatory efforts, had very few or no credit cards quickly transformed into a conspicuous consumption nation with consumers having an average of four credit cards per person. 23 Although such credit card spending admittedly spurred the Korean economy with a robust 10.9 percent GDP growth in 1999 followed by 9.3 percent growth in 2000.24 the problem was that consumers simply could not repay their credit card debts. In late 2002, for example, the Korean economy was weighed down by approximately US\$100 billion in credit card debt, equaling nearly 75 percent of Korea's 2003 total annual economic output. ${ }^{25}$ Witnessing the emerging credit card debt crisis, the Korean government was then under pressure to resolve the consumer credit card delinquency problem. What the government proposed came in the form of the Individual Debtor Rehabilitation Act ("IDRA" or "Act"). Members of the Korean National Assembly, Bae-sook Cho, Jung-bae Chun and others, supported and passed the Act on March 2, 2004, which became effective as of September 23, 2004.26 The Act stated that a person who can demonstrate "regular and consistent income" with debt not exceeding 1.5 billion won may be eligible for individual debtor rehabilitation. ${ }^{27}$ Moreover, IDRA covers debt obligations owed to both financial institutions and private liabilities. In such cases, the court of jurisdiction (which is the individual debtor's local court) restructures the debt in question and assists the debtor to reschedule owed debts by various methods, including the state's acquisition of the debtor's "property."

The definition of "property," under IDRA, includes 1) "all properties owned by the debtor up to the individual rescue process begins"; and 2) "all properties earned by the debtor during the individual rescue process." What is not included in the definition of "properties" are 1) "properties that cannot be seized"; 2) housing expenses and people supported by the debtor; and 3) six month living expenses for the debtor and people supported by the debtor. ${ }^{28}$ Thus, the more assets and property owned by a debtor, the more debtor protection that the local court may grant, since assets and properties are liquidated to pay back 
such owed debt obligations. However, how much the minimum repayment level should be is under the local court's sole discretion since the Act does not provide such exact amount relating to minimum repayment.

The objective of IDRA is to assist debtors rehabilitate his or her financial condition by rescheduling and/or forgiving past owed debts while simultaneously entering into workout programs with affected creditors. The underlying theory is that such efforts that will help rejuvenate the domestic economy, whereby the public funds appropriated for IDRA will be less than the added benefits to the Korean domestic economy in the form of an increase of individual consumers who can contribute to the state's tax revenues going forward. 29

\section{Korea Asset Management Corporation (KAMCO) and Bad Bank}

KAMCO was originally established pursuant to Article 53 of the Korea Development Bank Act in 1962 as a real-estate assets management agency. 30 Thereafter, on August 22, 1996, the "Law on Establishment of an Institution Exclusively Developed to the Efficient Resolution of Non-performing Loans of Financial Institutions and Distressed Companies" ("KAMCO Act") was enacted to expand KAMCO's scope of work to various areas in the Korean economy, from management of the insolvent obligations, assets, real-estate assets, debentures to the operation of non-performing loans ("NPLs"). 31 KAMCO also works on the management of government owned properties, resolutions of tax arrears, and most notably relating to this paper, supporting the recovery of consumer credit. Following the 1997-98 Korean financial crisis, in 2004, KAMCO introduced the Bad Bank Harmony Co. in 2004 ("Bad Bank")32 as another means to counter the Korean credit card polemic.

Attempting to recover from the 1997-1998 Korean financial crisis, the government induced many consumers to use credit cards to help boost consumer spending, which in part triggered the credit card debt crisis. Such debt crisis led to the default of many consumer loans, which led to a surge in NPLs, a core problem in the Korean economy following the 1997-98 Korean financial crisis. From a legal purview, NPLs are considered as loans that are delinquent for three months or longer. Pursuant to the KAMCO Act, article 3,33 after a financial institution transfers its NPLs to KAMCO, in exchange for an amount less than the original loan value, KAMCO will then transfer in part or whole the NPLs to Bad Bank. Bad Bank then either (i) pools such NPLs (sometimes in various asset classes) to form collateral upon which to issue one or more series of asset backed securities ("ABS"), typically to the offshore market in the form of high-risk high-yield medium-term notes ("MTNs"); or (ii) does not package such NPLs, but rather re-sell the NPLs to institutional bidders vis-à-vis international bidding and/or court auctions.

Bad Bank was originally initiated by $\mathrm{KAMCO}$ as a means to restructure the 
financial institutions after the 1997-1998 Korean financial crisis generally, but specifically and later, acted as a main body to resolve the credit card debtor "hangover." Specifically, KAMCO and Bad Bank attempted to 1) relieve financial institutions of their NPL polemic by purchasing such NPLs and then repackaging such seemingly unattractive assets into relatively attractive assets-backed securities; 2) invest in asset-management companies ("AMCs"); 3) buy and sell non-repackaged NPLs; and 4) provide funding to companies that were financially restructured by assisting in the purchase of real-estate properties. In short, Bad Bank wanted to ensure that assets with low or no potential were removed from the balance sheets of domestic entities, to help domestic entities thereby helping the domestic economy.

\section{Credit Counseling and Recovery Service (CCRS)}

By May 2002, the household loan lending (including credit card debt) amounted to 213.5 trillion won, which was a 31.9 trillion won increase from 2001, the year before. ${ }^{34}$ Koreans who failed to repay this loan and credit-card debt was being registered as "financially not eligible," which simply meant that these people were unable to make owed debt payments as scheduled. On the other hand, people who were able to pay were on the verge of credit default because of increased scrutiny placed on individual credit reports pursuant to added legislation, effective from July 2002.35

With the surge of debt defaulters in South Korea, the Financial Supervisory Service ("FSS") founded CCRS on October 1, 2002. The mandate of CCRS was to help credit defaulters recover from their dire economic conditions. One year later, on November 1, 2003, CCRS was approved by the FSS as a non-profit organization to participate in carrying out public services, such as credit counseling and managing finances of relevant debt defaulters. As of 2005, approximately 3,700 financial institutions joined the CCRS program. Under the FSS Act that established CCRS, individuals wanting to apply for this program must 1) be eligible in earning the minimum cost of living and/or paying back owed debt;

2) have less than 50 million won in more than two financial institutions; and 3) be registered on major credit-related institutions such as the National Banking Unions. 36

CCRS is designed to help defaulters who are willing and able to repay debts by a combination of one or more of the following: extending relevant payback dates for owed obligations: providing installments payments, readjusting interest rates (i.e., providing lower interest rates for longer payout timeframes), and reducing relevant owed debt levels. The ultimate goal of CCRS assistance is to prevent many households, particularly individuals living on minimum wage, from declaring bankruptcy, which creates a bad to worse economic scenario, both at the micro and macro levels. Table 2 below provides data relating to 
the growing pool of NPLs following the 1997-98 Crisis, with the peak levels in year 1999 and 2000. Table 3 below provides comparative data on NPLs with other industrialized nations, such as Japan, the United States, and Great Britain.

TABle 2. NonPerforming LOANS LeVEL 37

(Trillion won, \%)

\begin{tabular}{c|c|c|c|c|c|c|c|c|c}
\hline & '99 & ${ }^{\prime} 00$ & '01 & '02 & '03 & '04. 3 & '04. 6 & '04. 9 & '04. 12 \\
\hline NPL & 61.0 & 42.1 & 18.8 & 15.1 & 18.7 & 21.3 & 18.1 & 17.6 & 13.9 \\
\hline$\%$ & 12.9 & 8.0 & 3.41 & 2.33 & 2.63 & 2.93 & 2.46 & 2.37 & 1.90 \\
\hline
\end{tabular}

TABle 3. NPL LeVels FOR OTHER ADVANCED COUNTRIES

\begin{tabular}{c|c}
\hline Countries & NPL levels (as \% of total outstanding loans) \\
\hline Japan & $5.7 \%$ (March 2004) \\
\hline Germany & $4.6 \%$ (June 2004) \\
\hline Great Britain & $1.6 \%$ (March 2004) \\
\hline United States & $0.85 \%$ (September 2004) \\
\hline
\end{tabular}

\section{ANALYSIS OF THE LEGAL ACTS}

Given the notable scope and mandate of the Legal Acts and related debt relief programs covered in this paper, this section analyzes the potential winners and losers of such legislation, from both a legal and economic applied perspective.

In short, the potential winners are (i) qualified individual debtors who are effectively being "bailed out" of debt pursuant to the Act;38 (ii) foreign financial institutions that may be eager to purchase Korean won-denominated NPLs for future gain (with Table 4 below providing data as to the extent of the NPL polemic in Korea, following the 1997-98 Crisis); (iii) Korean institutions which will be able to receive injected public funds into its balance sheets vis-à-vis the Act; and (iv) from a political purview, the ruling South Korean Uri political party that helped to push the Act into passage on September 23, 2004, if the Legal Acts prove successful. The potential losers may be the Korean taxpayers who are effectively paying for the bail out of individual credit card debtors under the Act, and perhaps the reputation of the Korean financial infrastructure due to a "moral hazard" concern discussed herein.39

In terms of analysis, the Legal Acts were originally passed by the Korean National Assembly (legislative branch) with the view that the benefits of action outweighed the costs of inaction as it related to the Korean credit card crisis. Korean legislators, in other words, feared that action could potentially be more detrimental than inaction, from both an economic and social perspective. 40,41 
TABLE 4. NPL LEVELS FOR KOREA FROM 1997 TO 2005

\begin{tabular}{c|c|c|c|c}
\hline NPL levels & 1998 & 1999 & 2000 & 2001 \\
\hline Trillions of Korean won & 118 & 88 & 64.6 & 39.1 \\
\hline
\end{tabular}

SOURCE: Korea Asset Management Company (KAMCO) website, at http://www.kamco.or.kr/data/report/img/200411report07_06.pdf

On the one hand, the Legal Acts did admittedly result in some slight benefits in terms of rejuvenating Korea's financial infrastructure. For example, KAMCO's Bad Bank, at the end of 2004, reported that Korean banks' NPL level amounted to $1.90 \%$ of total loans, which was a $0.73 \%$ decrease from $2.63 \%$ in 2003.42 As Dong He (2004) alludes to, this figure is allegedly the lowest level since the Korean government began its legislative efforts in reducing NPL levels, following the 1997-98 Korean financial crisis.

On the other hand, however, the aggregate effect of the amount of individual credit card defaulters could place an extreme amount of stress upon the Korean financial infrastructure. 43 Thus if such lending institutions begin to fail (as in the case of LG Card, 44 formerly Korea's largest credit card company), then this could have led to a crisis in financial sector confidence. Because lending institutions are critical to the viability of the Korean economy, which is largely driven by large conglomerate growth (known as chaebol), 45 the fall of one lending institution may lead to a chain reaction of the fall of other lending institutions. This scenario could then ultimately lead to a 1929 pre-Great Depression style run on banks, and a drying up of all credit onshore in Korea, stifling the Korean economy and potentially plunging the eleventh largest global economy back into another 1997-98-type financial crisis. 46 Thus, implementing the Legal Acts represented a reactionary attempt to send a clear message to the markets that, first, the government recognized this potential risk, and second, that the language embedded in the Legal Acts, which would mitigate such potential events from occurring, which would in turn restore confidence back to the onshore markets.

CCRS shows the best results in helping the debtors in Korea. Since 2004, more than 493,018 people have requested to use the assistance of the Credit Counseling and Recovery Service, which led to 458,312 individuals were who granted appropriate debt relief, such as in the form of reduced interest rates and loan amounts. ${ }^{47}$ Not only did CCRS help individual debtors with financial aid, but CCRS also created 3,708 jobs and provided other financial counseling to help rehabilitate individual debtors who normally would not receive such beneficial services.

However, since CCRS provides debt relief to nearly all individuals who qualify on paper, one negative ramification of CCRS are individuals using CCRS services as a means of receiving debt relief even when not necessarily needed, so as to avoid or lower owed debt, which will almost always provided under CCRS 
so long as such individual earns "regular income," typically seen in cases where individuals have steady but low income levels, such as in government employees. Because CCRS provides a $50 \%$ write-off to what the government agency workers owe, these government agency workers can strategically use the system (to their favor but to the disfavor of the general public) by not disclosing their severance pay that is normally paid after employment termination. As evidence, up to September 2005, 0.6 billion won has been loaned by CCRS to the government agency workers. 48

Moreover, IDRA has also not measured up to expectations. Since 2004, 12,384 cases of legal counseling relating to individual debtor rehabilitation were submitted to the Korea Legal Aid Corporation. 49 Among the 12,384 cases, only 74 cases were successfully settled, and 98 cases were declared insolvent. ${ }^{50}$ However, IDRA is expected to experience a surge in counseling requests, expecting to rise up to 70,000 in 2005, which require the Korean Korea Legal Aid Corporation to take $20 \%$ of its work to IDRA-related counseling.

Government intervention opponents have several arguments opposing the Legal Acts. The first argument is that bailing out individual credit card holders create "moral hazard," 51 similar to the moral hazard created during the 1997-98 Crisis (Leipziger, 1998), which effectively creates an incentive for individuals to spend recklessly again in the future with little or no fear of the consequences related to debtor default simply because such debtors will expect to be bailed out again by the government at the taxpayers' expense 52 in the future. The second argument is that the Legal Acts may probably represent an inefficient use of taxpayers' money. The rationale is that taxpayer revenues should be used for such things as pension funds, healthcare, and crime prevention, rather than subsidizing the spending habits of Korean consumers. The third argument is that the Legal Acts may send a dangerous signal to the markets that the Korean government was in the business of acting as constant market surveyor ready to strike at any given moment when it perceives that designated price levels have somehow crossed a given line. 53 Investors enter into every transaction on the basis of caveat emptor. 54

However, if the government sends out signals that it is in the business of acting as market commentator - holding up red, yellow, and green lights as signals as to if, when, and how its populace should spend their money - then the country's public policy is to create a nation dependent on the government, which may not maximize total factor productivity (Lee, 1996), rather than the relevant individuals themselves. Related risks exist as well, which include inaccuracies of information, lags in receiving information, and lack of needed information in relation to setting forth such legislation.55,56 Further, one more pro-Legal Acts argument, which stems from the traditional Keynesian economic perspective, ${ }^{57}$ is that the role of government should be active, whereby the government can and should play a very hands-on management role over the 
public to help mitigate actual, threatened, or real market failures and instill public confidence in that a watchful force exists to protect consumers against financial turbulence and/or crisis. 58

\section{CONCLUSION}

The apparent negative externalities of the Korean credit card spending binge and subsequent 'hangover' have recently been met with strong market interventionist counter-action by the Korean government in the form of the recently instituted Legal Acts. The potential benefits of such legislation is that a massive influx of taxpayer capital will be reallocated to rescue credit card debtors to avoid the perceived potential of a rapidly downward spiraling financial infrastructure that could potentially mirror the 1997-98 Crisis. The potential downside is that the Legal Acts may lead to moral hazard whereby consumers will be given an incentive, or alternatively, little disincentive to not spend recklessly going forward, while valuable taxpayer revenue could instead be used for potentially more beneficial purposes if allocated elsewhere.

\section{REFERENCES}

Baily, Martin Neil and Philip Friedman. 1995. Macroeconomics, Financial Markets, and the International Sector. Richard D. Irwin, Inc. (2nd ed.).

Blaug, Mark. 1997-98. Economic Theory in Retrospect. Cambridge: Cambridge University Press (5th ed.)

Callahan, W. A. 1999. Negotiating Cultural Boundaries: Confucianism and transnational boundaries in Korea. Cultural Values 3(3): 329-364.

Chang, Ha-joon, Park, Hong-jae and Yoo, Chul-gyue. 1998. Interpreting the Korean crisis: financial liberalization, industrial policy, and corporate governance. Cambridge Journal of Economics 22(6): 735-46.

Choi, Gong-pil. 2004. Cause of Credit Defaulters and Its Countermeasures (Shinyong Bublangjab Keupjeungeub Woningwah dehchek). Korea Institute of Finance, Reports on Policy Research.

Crotty, James and Lee, Kang-kook. 2002. A political-economic analysis of the failure of neo-liberal restructuring post-crisis Korea. Cambridge Joumal of Economics 26(5): $667-678$.

Ernst and Young. 2002. Asia Non-Performing Loans Report, Asia Pacific Financial Solutions Group.

Financial Supervisory Service. 2005. www.fss.or.kr

Global Insolvency Law Database, The World Bank, "Individual Debtor Rehabilitation Act", "Korea Asset Management Corporation Act", "Credit 
Counseling and Recovery Service Act".

Haggard, Stephan and Jongryn Mo. 2000. The Political Economy of the Korean Financial Crisis. New York: Routledge.

He, Dong. 2004. The Role of KAMCO in Resolving Nonperforming Loans in the Republic of Korea. IMF Working Paper. WP/04/172.

Heo, Uk and Sunwoong Kim. 2000. Financial Crisis in South Korea: Failure of Government-Led Development Paradigm. Asian Survey 40(3): 492-507.

KAMCO. KAMCO Report. 1998-2004. Korea Asset Management and Corporation.

Kang, David. 2002. Crony Capitalism: Corruption and Development in South Korea and the Philippines. Cambridge: Cambridge University Press.

Kim, Dong-ki. 1992. Research on Korean Credit Card Policy: Its Problems and Plans for Reformation (Woori Nara Sbinyong Kadu Jeungchekeb Gwanhan Yungu: Keu MeunjebJunggwah Gebsubnbangabneul Joongshimeurob). Seoul: Korea University Press.

Kim, Jasper. 2005. Resolving South Korea's Credit Card Hangover: An Analysis of the Individual Debtor Rehabilitation Act. North Carolina Journal of International Law and Commercial Regulation 31(2).

Koo, Jaheyong and Kiser, Sherry L. 2001. Recovery from a Financial Crisis: The case of South Korea, Federal Reserve Bank of Dallas Economic and Financial Review.

Korea Institute of Finance. 2004. Confronting Strategy for the Credit Defaulter Problem. Korean Economic and Financial Outlook 13: 8.

Larkin, John. The House of Cards. Time Magazine Website, at http:/www.time. com/time/asia/magazine/article/0,13673,501031208-5521700,00.html. December 8, 2003.

Lee, H. K. 1998. Neoliberalism, Social Exclusion, and Welfare Clients in a Global Economy. International Journal of Social Welfare 8(1): 23.

Lee, Jong-wha. 1996. Government interventions and productivity growth. Joumal of Economic Growth 1(3): 391-414.

Leipziger, Danny M. 1998. Public and private interests in Korea: Views on moral bazard and crisis resolution. Economic Development Institute, Working Paper, World Bank.

Maeil Kyong-je News; Korean Website: www.mk.co.kr.

Mirrlees, J. A. 1999. The Theory of Moral Hazard and Unobservable Behavior: Part I. The Review of Economic Studies 66(1): 3-21.

Oh, Soo-Geun. 2004. Easy Understanding of the IDRA Process (Algeeh Sheewon GeinHwebSengJulcha). Seoul: Ewha Womans University Press.

Phelps, Edmund S. 1970. The Microeconomic Foundations of Employment and Inflation. New York: W. W. Norton.

Schofield, David. 2004. Korea: Bebind the crisis in South Korea's economy. Online Asia Times. 
Smith, Heather A., et al. 2001. Risk Management in Information Systems: Problems and Potential. Communications on the Association for Information Systems 7(August), Art 13 .

Stiglitz, Joseph E. and Andrew Murray Weiss. 1981. Credit Rationing in Markets with Imperfect Information. American Economic Review 71: 393-410.

Wu, Friedrich. 2003. Chinese Economic Statistics: Caveat Emptor. Post-Communist Economies 15(1): 127-145.

Yun, Seong-hun. 2002. Impact of Direct Regulations on the Korean Credit Card Market and Consumer Welfare. Institute for Monetary and Economic Research Economic Reports 7(1).

\section{ENDNOTES}

${ }^{1}$ For purposes of this paper, "South Korea", "ROK", and "Korea" (and any derivation thereof) shall, each and collectively, refer to the Republic of Korea.

2 "Default" and "credit delinquency" shall be used interchangeably for purposes of this paper, and shall be construed to mean non-payment of three (3) months or longer beyond a specified due date, as generally applied in practice in the Korean markets.

3 See John Larkin, The House of Cards, December 8, 2003, Time Magazine website, at http://www. time.com/time/asia/magazine/article/0,13673,501031208-552170,00.html [hereinafter Larkin].

${ }^{4}$ See David Schofield, Korea: Bebind the crisis in South Korea's economy, Online Asia Times, July 26, 2004.

${ }_{6}^{5}$ Id.

${ }^{6}$ See Larkin, at 3. See also Mike Weisbart, Taxes and Distribution: Slow Down, Korea Times, February 2, 2002, at http://times.hankooki.com/lpage/opinion/200602/kt2006020516063354190.htm.

${ }^{7}$ Id. On a related note, the overall post-1997-98 national policy thus helped banks and credit lending institutions. Such groups sought to benefit from credit card use mostly through credit card interest rates, which generally range from twenty to twenty-five percent in South Korea. Even more, unlike in the United States, Korean credit cards generally do not offer "revolving credit." The practical effect is that Korean consumers must pay off any charged amount by the next monthly payment period, which furthered the potential risk of debtor delinquency.

Much like in 1997-98, South Korea's economy currently suffers from lack of consumer domestic spending, which was one clear ramification of the 1997-98 Crisis. The reason for this was twofold. First, many Koreans saw their purchasing power drop substantially during the 1997-98 Crisis, which directly translated into fewer consumer purchases. Second, many Korean industries during the 1997-98 Crisis were forced into bankruptcy, which increased unemployment rates and dramatically deflated consumer confidence. Thus in the post 1997-98 Crisis economic environment, until 1999, when consumers faced the decision of spending now or not spending at all, consumers generally chose simply not to spend. However, from 1999 onwards, when the government began to promote the use of credit cards to individuals in an effort to spur domestic consumer spending, consumer spending behavior dramatically changed such that individuals spent money on credit in a far greater proportion than ever imagined by policymakers and credit-lending institutions, as noted by Yun (2002) relating to his research on how direct government regulation affected the credit card market. This ultimately led to binge credit spending and a notable over-spending "hangover" thereafter in the form of credit repayment delinquencies and debtor defaults.

${ }^{8}$ Gong Pil Choi, Cause of Credit Defaulters and Its Countermeasures (Shinyong Bublangjah Keupjeungeuh Woningwab debchek), Korea Institute of Finance, Reports on Policy Research (January, 2004).

9 Korea Institute of Finance, Confronting Strategy for the Credit Defaulter Problem. 2004. Korean Economic and Financial Outlonk 13: 8.

${ }^{10}$ Dong-ki Kim. 1992. Research on Korean Credit Card Policy: Its Problems and Plans for Reformation (Woori Nara Sbinyong Kadu Jeungchekeb Gwanhan Yungu: Keu MeunjebJunggwab Gebsubnbangabneul Joongsbimeuroh), Seoul: Korea University Press.

${ }^{11}$ Soo-Geun Oh. 2004. Easy Understanding of the IDRA Process (Algeeh Sheewon GeinHwebSengJulcba), Seoul: Ewha University Press.

${ }^{12}$ In particular, significant interest from global investment banks based in the Asia-Pacific region exist 
that cover the South Korean markets. Specifically, such interest is in part focused on the Korean consumer non-performing loan (NPL) market. If IDRA is effective at curing South Korea's creditor delinquency problem, then the NPL pool size may be less than if IDRA represents ineffective legislation that will not significantly curb the growing number of consumer defaults in South Korea. Often such NPLs are purchased by global investment banks, such as Morgan Stanley, Goldman Sachs, Deutsche Bank, and Lehman Brothers, to use as collateral for the issuance of high yielding asset-backed securities (ABS) vis-à-vis the use of a special purpose vehicle (SPV) as issuer domiciled in a tax-efficient jurisdiction, such as the Cayman Islands, Labuan, or Bermuda.

${ }^{13}$ For a paper focusing more on firm level credit problems, see Eduardo Borensztein and Jong-Wha Lee, Financial Crisis and Credit Crunch in Korea: Evidence from Firm Level Data, IMF Working Paper, January 2000, at 5 and 9 [hereinafter, Borensztein and Lee]. The paper argues that following the 1997-98 Crisis, credit was reallocated away from large Korean conglomerates (chaebol) to more "efficient" firms. For a more political economic perspective on the Korean 1997-98 Crisis, see generally, Stephan Haggard and Jongryn Mo, The Political Economy of the Korean Financial Crisis, Routledge Press (2000), at 197-218. In their text, the authors argue that the 1997-98 Crisis was caused by, first, a greater liberalization between state and business, and second, a timing conundrum in which the crisis occurred at an election year, which may have added both to the depth and severity of the 1997-98 Crisis.

${ }^{14}$ See Larkin, at 3.

${ }^{15}$ See Jahyeong Koo and Sherry L. Kiser. 2001. Recovery from a Financial Crisis: The Case of South Korea. Federal Reserve Bank of Dallas, Economic and Financial Review, at 25.

${ }^{16}$ As background, South Korean households went from being largely debt-free in 1997-98 to holding an average of US $\$ 27,000$ in debt per household in less than six years. Almost four million Koreans have defaulted on credit-card debt and household loans, a figure representing close to $10 \%$ of the country's population. The effect has been more than US $\$ 375$ billion in household debt. As one example of the dire effects relating to the credit card crisis, LG Card (South Korea's second largest credit card company at the time) collapsed in 2003, creating great concern in Korea about rising consumer debt and the fear of massive defaults. LG Card had started to rationalize its operations by disposing of some of its investments, including a $2 \%$ stake in LG Investments, estimated to be worth about US\$149 million. Struggling LG Card Co, received a vote of confidence after US broker Metrill Lynch announced on August 5, 2004 that it would buy US $\$ 400$ million of asset-backed bonds issued by LG Card. See Larkin, at 3 .

The South Korean ("ROK") government encouraged the growth of credit cards to boost consumer spending shortly after the 1997-98 Crisis but paid a heavy price in terms of defaults levels. Credit card companies and banks extended credit lines with little concern for repayment risk in the knowledge that the government wanted to increase debt spending, with the strong implication that credit was tacitly underwritten by the national treasury. In 2003, new legislation was passed mandating that credit-card firms curb their credit allocations, insist on credit checks and temper cash loans, known as the Regulation on Supervision of Credit-Specialized Financial Business (in which Chapter V relates to consumer protection and preservation of credit order). Id.

${ }^{17}$ See Larkin, at 2.

${ }^{18}$ See Schofield, at 3.

${ }^{19}$ However, countering such traditional ideals that stemmed in large part from the Korean Chosun period (1392-1910) were post-1997-98 modern Korean society individual demands and materialistic needs. Specifically, many Koreans, including many younger Koreans, saw credit cards as a relatively easy way in which to obtain the formerly unobtainable of high priced luxury goods.

${ }^{20}$ Jasper S. Kim. 2005. Resolving South Korea's Credit Card Hangover: An Analysis of the Individual Debtor Rehabilitation Act. North Carolina Journal of International Law and Commercial Regulation 31(2). ${ }^{21} \mathrm{Id}$.

${ }^{22} \mathrm{Id}$.

${ }^{23}$ John Larkin, The House of Cards, December 8, 2003, Time Magazine Website, at http://www.time.com/ time/asia/magazine/article/0,13673,501031208-5521700,00.html [hereinafter Larkin].

${ }^{24}$ Jaheyong Koo and Sherry L. Kiser. 2001. Recovery from a Financial Crisis: The case of South Korea. Federal Reserve Bank of Dallas, Economic and Financial Review, at 25.

${ }^{25}$ David Schofield, Korea: Behind the crisis in South Korea's economy, Online Asia Times, July 26, 2004. Notably, separate and distinguishable from the negative economic consequences of the credit card spending "hangover" came serious social problems. Domestic crime levels, prostitution, and insurance fraud cases increased, especially with the younger generation of Koreans who used credit cards as a form of over-leveraged short-term ticket to purchase luxury brand-name goods.

${ }^{26}$ Global Insolvency Law Database, The World Bank, "Individual Debtor Rehabilitation Act".

${ }_{28}^{27}$ IDRA, Article 2, explaining the sources of the 'incomes' of the candidates.

${ }^{28}$ IDRA, Article 3, definitions of 'properties'.

${ }^{29}$ The rationale behind the Korean National Assembly (legislative branch) passing the Act is tenuously predicated on the view by certain legislators that the benefits of the Act would outweigh its costs, 
since Korean legislators feared that legislative action to counter the credit card crisis would potentially be more detrimental than legislative inaction.

${ }^{30} \mathrm{KAMCO}$ website. (www.kamco.or.kr).

${ }^{31}$ Global Insolvency Law Database, The World Bank, "KAMCO Act".

${ }_{33}$ KAMCO website. (www.kamco.or.kr).

${ }^{33}$ Global Insolvency Law Database, The World Bank, "KAMCO Act", article 3.

34 "Introducing the Workout System for Multiple Debtors" Website: the Financial Supervisory Service. http://www.fss.or.kr/kor/search/search_total.jsp?WT.fss $=$ r5 51 .

${ }^{35}$ Id.

${ }^{36} \mathrm{Id}$.

${ }^{37} \mathrm{Id}$.

${ }^{38}$ Currently if an individual consumer had overdue debts of 300,000 Korean won for three months, such person would be classified as a "credit delinquent" and thereafter be placed on a creditor "black list" of the financial institutions. When an individual is deemed a "credit delinquent", the information would be kept by relevant financial institutions for a year. As IDRA effectively "rescues" (or bails out) a debtor from one's debt, the IDRA applicant may effectively be rescued, and thus, avoid the notorious title of "credit delinquent" and lower the likelihood and/or time of being placed on the "black list" used by Korean financial institutions.

${ }^{39}$ The issue of "moral hazard" can be evidenced in theory and practice in the South Korean case. For example, from late 2004, following IDRA's passage and various government official statements relating to individual debt assistance programs, debtor payments have dropped. Moreover, the Credit Recovery Committee reported that as of mid-December 2004, the number of debt adjustment applicants exceeded 1,000 per day. However, following Finance Minister Lee Hun-jai's January 7, 2005 statement that the ministry may exempt certain principal debts owed, the debt restructuring plan applicant levels dropped to 400 the next day. Further, an average of 4,000 consulting cases existed in November 2004 (following IDRA's September 2004 passage), which fell to 476 on January 8 (the day following Minister Lee's comments above). Taken from a big picture purview, this signals that debtors are waiting longer to repay debt obligations in the view that, "they will receive some sort of benefit" for possibly making payments at some point in the future rather than now. See JoongAng Daily Newspaper. January 18, 2005. Debtors abandon payments, at 3.

${ }^{40}$ The negative social (separate from economic) ramifications included increased reported cases of suicide, insurance fraud, and prostitution, among others.

${ }^{41}$ What may have been a primary driver behind such debt relief actions was the fear that not doing anything (i.e., inaction) could result in a financial crisis, similar to the 1997-98 Crisis. To work backwards, an argument that a possible financial crisis could be based on the sheer size and scope of individual credit card debt that existed in Korea, especially after 2002. Such credit card debt is effectively a loan with high interest rates (usually ranging from 20 to 25 percent) that should be repaid to the lending institution (usually domestic credit card companies or financial institutions). Thus if such debt is not repaid, this leads to a net loss equal to the expected original loan amount (principal) plus interest (expected profit from issuing the line of credit).

If only principal is repaid, then this in theory should amount to a neutral transaction, whereby neither upside nor downside is realized. However, if both principal (in part or full) and interest are not fully repaid, then a net loss exists within the balance sheet of the lending institution. For example, if lending institution A (lendor) lends US $\$ 100$ equivalent to lendee $B$ with a $20 \%$ interest rate charge, then lendor expects US\$100 (principal only) to US\$120 (principal plus interest) on its asset side of the balance sheet. Anything less will result in lost expected revenue, which hurts the financial viability of lending institution A.

${ }^{42}$ Bank of Korea. 2005. Evaluation of the Competitiveness of Domestic Large Commercial Banks. Financial System Review 12.

${ }^{43}$ The high risk of family credit default means that the nation's economy is still ailing amid ever-decreasing corporate investment, rising unemployment, intensifying labor disputes and rampant real estate speculation.

${ }^{44}$ In April 2004, Samsung Electronics spent nearly 600 billion Korean won to bail out its affiliate, Samsung Card Co., Korea's largest credit card issuer. Thereafter, Samssung Card Co. stated in January 2005 that it would raise 1.2 trillion won $(\$ 1.2$ billion) selling shares to its group affiliate, Samsung Electronics. Altogether, Samsung Electronics' actions represented two notable bailouts in one year. The funding structure is devised such that Sansung Card will sell 240 million new shares at 5,000 won per share in March 2005. Individuals and Samsung Card employees own a combined 11.7 percent stake in Samsung Card. Bloomberg News, quoted in the JoongAng Daily Newspaper. January 29, 2005. \$.2 billion bailout for card firm, at 3 .

${ }^{45}$ Four major credit card companies in Korea are Samsung Card Co., LG Card Co., Shinhan Card Co., and BC Card Co. Among these four, first two credit card companies-Samsung and LG-are the two largest conglomerates in Korean economy. 
${ }^{46}$ Borensztein and Lee, at 5-9, discussing the monetary causes of the South Korean "credit crunch". For a slightly more theoretical purview on credit rationing effects, see also generally, Joseph E. Stiglitz and Andrew Murray Weiss. 1981. Credit Rationing in Markets with Imperfect Information. American Economic Review 71: 393-410.

${ }^{47}$ Korean National Assembly Briefings. 2005-09-08. National Assembly in Korea. (http://www.news. go.kr/).

${ }^{48}$ Maeil Kyong-je Korean. November 25, 2004 (Website-http://search.mk.co.kr/contentView.php?doc$\mathrm{id}=373639 \& \mathrm{cid}=0$ ).

${ }^{49}$ Refer to the Korea Legal Aid Corporation website. http://www.klac.or.kr/index2.php. 2005-08-21. ${ }^{50} \mathrm{Id}$.

${ }^{51}$ The definition of "moral hazard" is "The risk that the presence of a contract will affect on the behavior of one or more parties." The classic example is in the insurance industry, where coverage against a loss might increase the risk-taking behavior of the insured, See Investorwords website, at http://www.investorwords.com/3117/moral hazard.html. For an interesting article relating to the issue of moral hazard, see J.A. Mirrlees. 1999. The Theory of Moral Hazard and Unobservable Behaviour: Part 1. The Review of Economic Studies 66(1): 3-21.

${ }^{52}$ As a matter of practice, separate from theory, government action to relieve the debts of individuals made the credit delinquents to make less effort to pay what they owe. After the government announced on January 7, 2005 that the Ministry of Finance and Economy would look into exempting the principal debts, debts adjustment consulting requests to the Credit Recovery Committee fell from average 4,000 a day in November 2004 to 476 on January 8, 2005. See, JoongAng Daily. January 18, 2005. Debtors abandon payments, at 3.

${ }^{53}$ The main problem in this scenario is that such instant price deflation towards a certain designated level would be chosen not by the markets, as in most developed nations, but by government bureaucrats.

${ }^{54}$ Latin meaning "let the buyer beware."

${ }^{55}$ One of the well-known examples on incomplete information is "the parable of separate islands." This concept was first introduced by Edmund S. Phelps. 1970. The Microeconomic Foundations of Employment and Inflation (New York: W.W. Norton). Robert Lucas used this parable to explain the concept of incomplete information. In his explanation Lucas made up the economy with one single business unit based in a separate island, such as no one knows what happens on other separate islands. With this lack of information, the investor based in the separate island can make incorrect investment decisions. Therefore, incomplete information may increase the risk much more than expected. See Martin Neil Baily and Philip Friedman. 1995. Macroeconomics, Financial Markets, and the International Sector (Richard D. Irwin, Inc., $2^{\text {nd }}$ ed.).

${ }^{56}$ In short, the public policy message that the Legal Acts may signal is that individual debtors need not evaluate relevant risks relating to their personal expenditures because the government will do the analysis for them and bail them out when deemed necessary.

${ }^{57}$ Regarding Keynesian economic theory, "The fundamental lesson of Keynesian economics is that the automatic adjustment mechanism of competition cannot be relied upon to achieve such policy objectives as full employment and price stability. The main message of Keynesian economists is that the automatic adjustment process of the market is too unreliable to serve as a practical basis of full-employment policy." See Mark Blaug, Economic Theory in Retrospect (Press Syndicate of the University of Cambridge, 5th ed., 1997-98).

${ }^{58}$ However, after 1997 Korean economic crisis, some academics blamed the government led economic development as the main reason for the economic crisis, claming for market-oriented economic development would be necessary to overcome the economic crisis and to develop Korean economy further. See, Uk Heo and Sunwoong Kim. 2000. Financial Crisis in South Korea: Failure of Government-Led Development Paradigm. Asian Survey 40(3): 492-507. 